\title{
How can a seemingly weak state in the financial services industry act strong? The role of organizational policy capacity in monetary and macroprudential policy
}

\section{Caner Bakır' and Mehmet Kerem Çoban²}

\begin{abstract}
It is widely held in the public policy and political economy literatures that the Turkish state is weak and cannot adopt a proactive approach in the financial services industry by steering and coordinating the financial policy network. However, it is puzzling that this seemingly "weak" Turkish state, which is often marked by fragmentation, conflict, and a lack of policy coordination within the state apparatus, acted strongly between 2010 and 2016 by taking pre-emptive measures to contain the macrofinancial risks arising from hot money inflows and bank credit expansion. Examining the organizational policy capacity of the Central Bank of the Republic of Turkey, this article argues that proactive policy design and implementation are more likely to complement state capacity when the principal bureaucratic actors have strong organizational policy capacities.
\end{abstract}

Keywords: Policy capacity; state; Turkey; Central Bank; financial stability

\footnotetext{
${ }^{1}$ Caner Bakır, Department of International Relations, College of Administrative Sciences and Economics, and GLODEM, Koç University, Rumelifeneri Yolu, 34450, İstanbul; cbakir@ku.edu.tr.

${ }^{2}$ Mehmet Kerem Çoban, GLODEM, Koç University, Rumelifeneri Yolu, 34450, Istanbul; m.keremcoban@ u.nus.edu.

Authors' Note: We are very grateful to Sinan Akgünay for his comments and suggestions on earlier versions of this article. We thank the interviewed officials for their openness in their responses. An earlier version of this article was presented at the 25th IPSA World Congress of Political Science, held in Brisbane, Australia on July $21-25,2018$, and we thank panel participants for their constructive comments. We also very much appreciate the constructive comments of three anonymous referees and the editors of the journal. Mehmet Kerem Çoban would like to gratefully acknowledge the generous financial support of the Academic Support Fund of the Lee Kuan Yew School of Public Policy, National University of Singapore.
} 


\section{Introduction}

Research suggests that evidence-based policymaking at the bureaucratic level ${ }^{1}$ can face challenges arising from various sources, such as a disconnection between researchers and policymakers; ${ }^{2}$ sociopolitical constraints; ${ }^{3}$ and/or deficiencies in the "problem-solving capacity" of the state, bureaucracies, and/or individual policymakers. ${ }^{4}$

Given the prominence of policy design and implementation in the postGlobal Financial Crisis (GFC) era, ${ }^{5}$ this article aims to investigate when and how organizational policy capacity is more likely, and whether it can, contribute to state capacity to respond proactively to the complex policy challenges posed by the financial globalization process. In this regard, the article examines the organizational policy capacity of the Central Bank of the Republic of Turkey (Türkiye Cumburiyeti Merkez Bankast, hereafter the Central Bank), which informed monetary policy and macroprudential policy design and implementation in Turkey between 2010 and 2016. It finds that the Central Bank's organizational policy capacity played a critical role in the Turkish state's capacity to proactively manage the adverse effects of speculative, short-term, and unproductive capital (i.e., hot money) inflows in the post-GFC period. We argue that the design and implementation of proactive policy measures are more likely when the principal bureaucratic actors have a strong organizational policy capacity, including analytical, operational, and political capacities. In such cases, these actors complement the state capacity to respond to policy challenges such as macrofinancial risks, including excess credit growth, household debt, the appreciation of domestic currency, and a widening current account deficit.

Our findings and argument challenge the conventional wisdom in the literature, where it is widely held that the Turkish state is weak and cannot

1 For a review, see Joshua Newman, "Deconstructing the Debate over Evidence-based Policy," Critical Policy Studies 11, no. 2 (2017): 211-226.

2 Michael Howlett, "Policy Analytical Capacity and Evidence-based Policy-making: Lessons from Canada," Canadian Public Administration / Administration Publique du Canada 52, no. 2 (2009): 153-175; Lawrence M. Mead, "Only Connect: Why Government Often Ignores Research," Policy Sciences 48, no. 2 (2015): 257-272; Brian W. Head, "Reconsidering Evidence-based Policy: Key Issues and Challenges," Policy and Society 29, no. 2 (2010): 77-94.

3 Arnold J. Meltsner, "Political Feasibility and Policy Analysis," Public Administration Review 32, no. 6 (1972): 859-867.

4 Martin Lodge and Kai Wegrich, eds., The Problem-solving Capacity of the State: Governance Challenges and Administrative Capacities (Oxford: Oxford University Press, 2014); Joshua Newman et al., "Policy Capacity and Evidence-based Policy in the Public Service," Public Management Review 19, no. 2 (2017): 157-174.

5 Caner Bakır and J.J. Woo, "Financial Sector Reform and Policy Design in an Age of Instability," Policy and Society 35, no. 3 (2016): 193-204; Caner Bakır, "How Can Interactions among Interdependent Structures, Institutions, and Agents Inform Financial Stability? What We Have Still to Learn from Global Financial Crisis," Policy Sciences 50, no. 2 (2017): 217-239. 
adopt a proactive approach in the financial services industry. ${ }^{6}$ This is said to be due to "fragmentation," "a lack of coordination and institutionalized consensus building" among the key actors, and lack of "shared vision" and "policy coherence" in the state apparatus. ${ }^{7}$ However, the Turkish experience in monetary and macroprudential policy design and implementation in the post-GFC period actually shows otherwise. ${ }^{8}$

Specifically, in the post-GFC structural material context, quantitative easing by central banks in developed countries led to a surge in hot money flows to developing countries between 2009 and 2016. ${ }^{9}$ This exogenous shock resulted in a real appreciation of national currency and in excessive bank credit growth, which contributed to a widening current account deficit. These macrofinancial risks have been the main sources of macrofinancial instability and financial crises in developing countries, including Turkey. ${ }^{10}$ Indeed, in Turkey such capital flows led to the build-up of macrofinancial risks in the form of excess credit growth and leverage, low levels of domestic savings, a deterioration in the current account and the quality of external funding, and an increasing dependency on hot money flows. ${ }^{11}$ Unsurprisingly, the Turkish economy thereby became

6 Caner Bakır, "Governance by Supranational Interdependence: Domestic Policy Change in the Turkish Financial Services Industry," in Emerging European Financial Markets: Independence and Integration Post- Enlargement, ed. Jonathan Batten and Colm Kearney (London: Elsevier, 2006), 204; Caner Bakır, "Bargaining with Multinationals: Why State Capacity Matters," New Political Economy 20, no. 1 (2015): 63-84; Caner Bakır, Merkezdeki Banka ve Uluslararası Bir Karşılaştırma (İstanbul: Bilgi University Press, 2007); Caner Bakır, “Türkiye Cumhuriyet Merkez Bankası'nın 1930-2001 Arasında Siyasal ve Ekonomik Bağımsızlığı: Siyasal-Ekonomik Etkileşime İlişkin Karşılaştırmalı Bir Çözümleme," METU Studies in Development 33, no. 1 (2006): 1-31.

7 Bakır, "Governance by Supranational Interdependence"; Bakır, "Bargaining with Multinationals."

8 For an exception, see Mehmet Kerem Çoban, "Compliance Forces, Domestic Policy Process, and International Regulatory Standards: Compliance with Basel III," Business and Politics (2019). doi: 10.1017/bap.2019.3.

9 International Monetary Fund (IMF), "Recent Experiences in Managing Capital Flows: Cross-Cutting Themes and Possible Policy Framework" (Washington, DC: International Monetary Fund, 2011), https://www.imf.org/external/np/pp/eng/2011/021411a.pdf; Mercedes Garcia-Escribano and Fei Han, "Credit Expansion in Emerging Markets: Propeller of Growth?" IMF Working Papers no. 15/22 (Washington, DC: International Monetary Fund, 2015); Hakan Kara, "Turkey's Experience with Macroprudential Policy," BIS Papers 86 (2016): 123-139.

10 Yilmaz Akyüz and Korkut Boratav, "The Making of the Turkish Financial Crisis," World Development 31, no. 9 (2003): 1549-1566; Caner Bakır and Ziya Öniş, "The Regulatory State and Turkish Banking Reforms in the Age of Post-Washington Consensus," Development and Change 41, no. 1 (2010): 77-106; Carmen M. Reinhart and Vincent Reinhart, "Capital Flow Bonanzas: An Encompassing View of the Past and Present," NBER International Seminar on Macroeconomics 5, no. 1 (2008): 9-62; IMF, Increasing Resilience to Large and Volatile Capital Flows: The Role of Macroprudential Roles - Case Studies (Washington, DC: International Monetary Fund, 2017), https://www.imf.org/ en/Publications/Policy-Papers/Issues/2017/09/13/pp062117increasing-resilience-macroprudentialpolicies-case-studies.

11 Hakan Kara, "Monetary Policy in Turkey after the Global Crisis," CBRT Working Paper no. 12/17 (Ankara: Central Bank of Republic of Turkey, 2012); Kara, "Turkey's Experience with Macroprudential Policy." 
vulnerable to sudden stop and capital outflows. However, in contrast to Turkey's previous experiences in the 1994 and 2001 financial crises, such hot money inflows did not result in currency, banking, or balance of payments crises. Indeed, the International Monetary Fund (IMF) noted that Turkey "successfully curbed credit growth." ${ }^{12}$ As Central Bank senior officials emphasized the decline in the annual growth rate of consumer loans, the initial rising trend in the household indebtedness ratio became a declining trend, as well as improvement in the current account deficit and the quality of its funding. ${ }^{13}$ Perhaps more strikingly, research by the Central Bank showed that, by 2013, "the Turkish lira [had] become one of the least volatile currencies among emerging market economies" in the post-GFC era. ${ }^{14}$ But why was it different this time?

The Central Bank designed and implemented a "new policy mix" in November 2010, when policy rate and reserve requirements were used, along with an asymmetric interest rate corridor and a reserve options mechanism, in order to manage capital flows. ${ }^{15}$ More significantly, the bank was the key actor in the formation of the Financial Stability Committee (Finansal İstikrar Komitesi, FIK) in June 2011. ${ }^{16}$ The establishment of the FIK was pivotal in strengthening state capacity to proactively respond to the macrofinancial challenges posed by hot money flows. This was because various state actors in the financial services industry now began coordinating, cooperating, and collaborating in monetary and macroprudential policy design and implementation. ${ }^{17}$

$12 \mathrm{IMF}$, Increasing Resilience, 71. For causal mechanisms triggered by macroprudential instruments that generate effective policy outcomes by operating in appropriate contexts, see Caner Bakır, "Actions, Contexts, Mechanisms and Outcomes in Macroprudential Policy Design and Implementation," Public Policy and Administration (2019), doi: 10.1177/0952076719827057.

13 Kara, "Turkey's Experience with Macroprudential Policy," 131-136.

14 Koray Alper et al., "Alternative Tools to Manage Capital Flow Volatility," BIS Papers no. 73 (2013), 351.

15 For in-depth discussion of the new policy mix and macroprudential measures, see Erdem Başçı and Hakan Kara, "Finansal Istikrar ve Para Politikası," Working Paper no. 11/08 (Ankara: Central Bank of the Republic of Turkey, May 2011); Hakan Kara, "Monetary Policy in Turkey after the Global Crisis," Working Paper no. 12/17 (Ankara: Central Bank of the Republic of Turkey, June 2012); Ahmet Faruk Aysan et al., "Macroprudential Policies as Buffer against Volatile Cross-border Capital Flows," The Singapore Economic Review 60, no. 1 (2015): 1-6; Yasin Akcelik et al., "Central Banking in Making during the Post-crisis World and the Policy-Mix of the Central Bank of the Republic of Turkey," Journal of Central Banking Theory and Practice 2, no. 2 (2013): 5-18; Refet S. Gürkaynak et al., "Monetary Policy in Turkey after Central Bank Independence," iktisat, Işletme ve Finans 30, no. 356 (2015): 9-38.

16 Hakan Kara, "Turkey's Experience with Macroprudential Policy"; Mustafa Yağcl, "Institutional Entrepreneurship and Organisational Learning: Financial Stability Policy Design in Turkey," Policy and Society 36, no. 4 (2017): 539-555.

17 The FiK was chaired by the Minister of the Treasury, who would brief the Council of Ministers regarding the results of FiK meetings and decisions. The remaining principle decision makers at the FiK who were involved in the analysis, development, and implementation of macrofinancial stability measures included the governor of the Central Bank, the chairman of the BDDK, and the undersecretary of the treasury. The remaining members of the FiK were the head of the Savings Deposit Insurance 
As a result, the Banking Regulation and Supervision Agency (Bankactlk Düzenleme ve Denetleme Kurumu, BDDK), which had previously been preoccupied with microprudential measures, now introduced macroprudential regulatory measures and started working closely with the Central Bank. It is puzzling that the supposedly weak state acted strongly by adopting such a proactive monetary policy and complementary macroprudential policy measures in order to effectively address macrofinancial risks. ${ }^{18}$ In the words of one deputy governor, "Turkey has adopted a policy mix of tight monetary policy along with accommodative macroprudential and fiscal policies [that has] helped to strengthen price, financial, and macroeconomic stability." 19 This episode deserves investigation, because it shows that the weak state capacity in the financial services industry in Turkey can be complemented by a strong policy capacity at the bureaucratic level. Furthermore, recent research shows that the Central Bank has a strong organizational policy capacity. ${ }^{20}$ However, our knowledge of the sources of organizational policy capacity and how they enable the Central Bank to play a leading role in the state's attempt to contain macrofinancial risks (i.e., organizational policy capacity in action) is limited. This article aims to fill these gaps in the literature. Our findings show that the Central Bank's organizational policy capacity is one of the key factors that enabled the Turkish state to take preemptive measures to contain the macrofinancial risks arising from hot money flows.

The theoretical perspective adopted in this article builds upon recent theoretical advances in the policy capacity scholarship. ${ }^{21}$ While the article sheds light upon the enabling conditions for organizational policy capacity and its role in improving state capacity, it also contributes to various strands in the broader public policy literature. First, this article is the first step forward toward linking

Fund (Tasarruf Mevduatı Sigorta Fonu), the key authority on the bank resolution framework, and the head of the Capital Markets Board (Sermaye Piyasası Kurulu), a disclosure regulator. However, these actors were not directly involved in macroprudential policy design and implementation processes.

18 For a similar puzzle in the Australian context, see Caner Bakır, "The Governance of Financial Regulatory Reform: The Australian Experience," Public Administration 87, no. 4 (2009): 910-922.

19 Murat Uysal, "Financial Stability and Macroprudential Policy in Turkey," BIS Papers 94 (2017), 249.

20 Caner Bakır and Mehmet Kerem Çoban, "Policy Analysis and Capacity in the Central Bank of Turkey," in Policy Analysis in Turkey, ed. Caner Bakır and Gunes Ertan (Bristol: Policy Press, 2016): 215-233.

21 See Howlett, "Policy Analytical Capacity and Evidence-based Policy-making"; Samuel Oliphant and Michael Howlett, "Assessing Policy Analytical Capacity: Comparative Insights from a Study of the Canadian Environmental Policy Advice System," Journal of Comparative Policy Analysis: Research and Practice 12, no. 4 (2010), 439-440; Xun Wu et al., "Policy Capacity: A Conceptual Framework for Understanding Policy Competences and Capabilities," Policy and Society 35, no. 3-4 (2015), 166. See also Xun Wu et al., "Policy Capacity: Conceptual Framework and Essential Components," in Policy Capacity and Governance: Assessing Governmental Competences and Capabilities in Theory and Practice, ed. Xun Wu, Michael Howlett, and M. Ramesh (Cham: Palgrave Macmillan, 2018): 125; Michael Howlett and M. Ramesh, "The Two Orders of Governance Failure: Design Mismatches and Policy Capacity Issues in Modern Governance," Policy and Society 33, no. 4 (2014), 322. 
the organizational policy capacity with the state capacity. Second, it responds to calls that there is "little empirical evidence or systematic research" in policy analytical capacity. ${ }^{22}$ Third, the article is, to the best of our knowledge, the first in the public policy literature to link the sources of organizational policy capacity with policy actions in central banking, whether in a developing or a developed country. Specifically, it links the policy analysis and capacity literatures, which have been grossly neglected so far, with central banking. ${ }^{23}$

The remainder of this article is divided into four sections. The first section introduces the key relevant concepts and approaches via a review of the public policy literature, with a particular emphasis on organizational policy capacity and state capacity. The second section introduces the research design. This is followed by a discussion of how the Central Bank's organizational policy capacity strengthens state capacity in Turkey. Finally, the concluding section summarizes the main findings and discusses the implications for future research.

\section{Literature review}

\section{Policy capacity and state capacity}

Policy capacity is "the set of skills and resources-or competences and capabilities-necessary to perform policy functions." ${ }^{24}$ As such, it is defined here as an organization's resources and skills for making and implementing sound policy decisions. ${ }^{25}$ The lack of such a capacity can impede informed policy design and implementation. ${ }^{26}$

There are three dimensions of policy capacity at the bureaucratic level: organizational analytical capacity, organizational operational capacity, and organizational political capacity. ${ }^{27}$ The first of these, analytical policy capacity, requires "a recognized requirement or demand for research (a market), a supply of qualified researchers, [and] ready availability of quality data, policies, and procedures to facilitate productive interactions with other researchers,

22 Oliphant and Howlett, "Assessing Policy Analytical Capacity."

23 For an exception, see Kranit Flug, "Policy Analysis in the Bank of Israel," in Policy Analysis in Israel, ed. Gila Menahem and Amos Zehavi (Bristol: Policy Press, 2016): 141-152. Nonetheless, there the author only discusses the organizational structure and the process of policy analysis.

24 Wu et al., "Policy Capacity: A Conceptual Framework," 166; Wu et al., "Policy Capacity: Conceptual Framework and Essential Components."

25 Michael Howlett and M. Ramesh, "Achilles' Heels of Governance: Critical Capacity Deficits and Their Role in Governance Failures," Governance 10, no. 4 (2016): 301-313.

26 Michael Howlett, "The Criteria for Effective Policy Design: Character and Context in Policy Instrument Choice," Journal of Asian Public Policy 11, no. 3 (2018): 245-266; Newman et al., "Policy Capacity and Evidence-based Policy in the Public Service."

27 Wu et al., "Policy Capacity: A Conceptual Framework," 167. 
and a culture in which openness is encouraged and risk taking is acceptable." 28 It "help[s] to ensure [that] policy actions are technically sound in the sense [that] they can contribute to [the] attainment of policy goals." ${ }^{29}$ In the context of central banking, we consider analytical capacity to be the capacity to gather, process, and analyze relevant information and data for policy design and experimentation. ${ }^{30}$

Organizational operational capacity "allows [for] the alignment of resources with policy actions so that they can be implemented in practice." ${ }^{31}$ In this regard, for an organization to implement policies, it needs strong intellectual leadership and a quality human resource base, as well as intra- and interorganizational coordination of processes, a commitment to achieving goals, professional and departmental autonomy, and fiscal and personnel resource availability. ${ }^{32}$ Finally, there is also organizational political capacity, which "helps to obtain and sustain political support for policy actions." ${ }^{33}$ This is because "policy capacity is also shaped by the political resources [e.g., the political legitimacy of an organization, the level of access to key policymakers, and communication with stakeholders and the general public] that an agency enjoys for performing its functions." 34

Although there is no consensus on the definition of state capacity in the public policy and political economy literatures, ${ }^{35}$ it generally refers to "the government's ability to formulate, pursue, and implement its policies." ${ }^{36}$ Bakır notes that "administrative and institutional capacity [are the] key interrelated

28 Norman Riddell, Policy Research Capacity in the Federal Government (Ottawa: Policy Research Initiative, 2007), 5; cited in Oliphant and Howlett, "Assessing Policy Analytical Capacity," 440.

29 Wu et al., "Policy Capacity: A Conceptual Framework," 167-168; emphasis in original.

30 Dave Huitema et al., "Policy Experimentation: Core Concepts, Political Dynamics, Governance and Impacts," Policy Sciences 51, no. 2 (2018): 143-159.

31 Wu et al., "Policy Capacity: A Conceptual Framework," 168; emphasis in original.

32 Wu et al., "Policy Capacity: Conceptual Framework and Essential Components," 10.

33 Wu et al., "Policy Capacity: A Conceptual Framework," 168; emphasis in original.

34 Wu et al., "Policy Capacity: Conceptual Framework and Essential Components," 10-11.

35 Peter B. Evans, Dietrich Rueschemeyer, and Theda Skocpol, eds., Bringing the State Back In (Cambridge: Cambridge University Press, 1985); Francis Fukuyama, State-Building: Governance and World Order in the 21st Century (Ithaca, NY: Cornell University Press, 2003); Peter B. Evans, Embedded Autonomy: States and Industrial Transformation (Princeton, NJ: Princeton University Press, 1995); Martin Painter and Jon Pierre, "Unpacking Policy Capacity: Issues and Themes," in Challenges to State Policy Capacity: Global Trends and Comparative Perspectives, ed. Martin Painter and Jon Pierre (London: Palgrave Macmillan, 2005): 1-18.

36 Caner Bakır, Bank Behaviour and Resilience: The Effects of Structures, Institutions and Agents (Basingstoke: Palgrave Macmillan, 2013), 55; see also William D. Coleman, Financial Services, Globalization and Domestic Policy Change (New York: St. Martin's Press, 1996); Linda Weiss, The Myth of the Powerless State: Governing the Economy in a Global Era (Ithaca, NY: Cornell University Press, 1998); Theda Skocpol, "Bringing the State Back In: Strategies of Analysis in Current Research," in Bringing the State Back In, ed. Peter B. Evans, Dietrich Rueschemeyer, and Theda Skocpol (Cambridge: Cambridge University Press, 1985): 3-37. 
dimensions" of state capacity. ${ }^{37}$ In this respect, state capacity also relates to "governance capacity"; i.e., "the resources and skills a government requires to steer a governance mode so as to make sound policy choices and implement them effectively." ${ }^{38}$ State capacity constrains or enables policymakers' decision to choose whether to follow an anticipatory or reactive approach to policymaking in the financial services industry. ${ }^{39}$ Weak states are assumed to adopt reactive policies in response to pressures originating from markets. Coleman offers a state capacity framework in the financial services industry, outlining how a state's strengths and weaknesses in financial market governance are based on (1) the degree to which ultimate decision-making power is concentrated in the hands of a relatively small number of officials, and (2) the balance between the perspectives of central banks and finance ministries. ${ }^{40}$ Drawing on this framework, the conventional wisdom in connection with Turkey holds as follows:

Turkey has been characterized by fragmentation and a lack of coordination and institutionalized consensus building among supervisors [in the financial services sector] [...] Apart from this fragmented state apparatus in [the] financial services industry, there were also conflict of interest problems and [a] lack of adequate cooperation among financial supervisors [...] [A] proactive approach in the financial services industry by steering and coordinating policy community does not exist $[\ldots][\mathrm{A}]$ degree of centralization of the state apparatus (or regulatory/supervisor consolidation), and the existence of institutional arrangements, which ensure a balance between the perspectives of the [BDDK], [the] Treasury, and the Central Bank, are needed. As such, the Turkish state is weak and cannot adopt a proactive approach in the financial services industry by steering and coordinating [the] policy community. ${ }^{41}$

In contrast, this article argues that the seemingly weak Turkish state acted strongly in the financial services industry due to the Central Bank's strong organizational policy capacity.

The administrative dimension of state capacity is closely related to organizational policy capacity at the bureaucratic level. This dimension refers to the efficient management of the human and physical resources necessary for the

37 Caner Bakır, "Bargaining with Multinationals," 69.

38 Howlett and Ramesh, "The Two Orders of Governance Failure," 322.

39 Coleman, Financial Services, Globalization and Domestic Policy Change, 67-94; Caner Bakır, "The Australian Experience."

40 Coleman, Financial Services, Globalization and Domestic Policy Change, 67-94; see also John Zysman, Governments, Markets, and Growth: Financial Systems and the Politics of Industrial Change (Ithaca, NY: Cornell University Press, 1983); Peter J. Katzenstein, Between Power and Plenty: Foreign Economic Politics of Advanced Industrial States (Madison: University of Wisconsin Press, 1978).

41 Caner Bakır, "Governance by Supranational Interdependence," 192, 193, 204. 
delivery of government outputs. ${ }^{42}$ This requires the identification of policy problems and effective policy design and implementation. Organizational policy capacity at the bureaucratic level enables the alignment of resources, the development of analytically sound policies, and a build-up of political support. As such, a greater organizational policy capacity enhances the administrative dimension of state capacity and is in fact essential for effective policy design and implementation. Furthermore, it is also critical for state capacity to manage the impact of globalization on administrative capabilities in regards to effective policy design and implementation. ${ }^{43}$ Thus, here we conceptualize state capacity as the state's capability to respond proactively to the complex policy challenges posed by financial globalization through a portfolio of policy instruments.

\section{Method}

This article adopts an explanatory case study method. ${ }^{44}$ This is because we are focusing on an analysis of a contemporary phenomenon in its real-life context, where we have no control over the dependent and independent variables; we pose questions of why and how; we use multiple sources of evidence; and we aim to explain the causal relationship between organizational policy capacity and state capacity.

Interviews and written data have been used in the data collection process. A series of 60-minute semi-structured elite interviews with open-ended questions were conducted between 2013 and 2019. The interviewees included eight senior public officials: four senior people associated with the Central Bank (a former governor, two deputy governors, and a former director general of the Research and Monetary Policy Department [Araştırma ve Para Politikast Genel Müdürlüğ̈̈]), two senior banking regulators (a former senior banking specialist and a deputy chairman), and two senior treasury officials (the head of the Directorate General of Financial Sector Relations and Exchange [Mali Sektörle İlişkiler ve Kambiyo Genel Müdürlüğ̈̈ ${ }^{45}$ ] and a former acting deputy undersecretary).

Our data collection and analyses processes were iterative. Thus, there were several rounds of interviews continuing until additional interviews yielded no new information. The views endorsed by most of this cross-section of elite

42 Painter and Jon Pierre, "Unpacking Policy Capacity: Issues and Themes," 2.

43 Michael Howlett and M. Ramesh, "Globalization and the Choice of Governing Instruments: The Direct, Indirect, and Opportunity Effects of Internationalization," International Public Management Journal 9 , no. 2 (2006): 175-194.

44 Robert K. Yin, Case Study Research: Design and Methods (Thousand Oaks, CA: Sage, 1994).

45 This institution has recently had its name changed to the Directorate General of Financial Markets and Exchange (Finansal Piyasalar ve Kambiyo Genel Müdürlüğü). 
decision makers are anonymized, and they informed the analysis in this article. Furthermore, in terms of written sources, in-depth analysis of primary and secondary written sources were used to support the dataset obtained from the interviews. These sources included newspapers, academic publications, and the official reports of public bureaucracies and international intergovernmental organizations. These served as triangulation and supplementary sources for the interview data.

The temporal context began in November 2010, when the surge in hot money flows resulted in macrofinancial risks that required a new monetary policy mix and macroprudential tightening in order to contain bank balance sheet growth. It ended following the failed coup attempt of July 15, 2016, which necessitated a reversal of tight policy measures so as to stimulate bank credit expansion in response to the subsequent decline in hot money and credit flows that resulted in economic contraction.

\section{Organizational policy capacity in action}

Organizational structure relates to factors that facilitate or impede evidencebased policymaking and policy experimentation through the utilization of policy analysis and research. In this regard, it is useful to note that the Central Bank has gradually moved from a hierarchical organizational structure to a horizontal one, which facilitates greater interdepartmental interaction, communication, and collaboration. ${ }^{46}$ The formal organization of the Central Bank relates to its analytical and operational organizational capacity. In this respect, three departments play a crucial role: the Research and Monetary Policy Department, the Statistics Department (İstatistik Genel Müdürlüğ̈̈), and the Banking and Financial Institutions Department (Bankacilik ve Finansal Kuruluşlar Genel Müdürlüğ̈̈). These departments contribute to the organizational analytical capacity in support of price stability and financial stability. ${ }^{47}$ They also play significant interrelated and complementary roles in policy analysis.

The post-GFC period of 2009 and 2010 proved a challenging environment for developing countries, as loose monetary policies (i.e., quantitative easing) in developed countries led to a surge in destabilizing hot money inflows to

46 Caner Bakır, "Organizational Change in Economic Bureaucracy in Turkey, 1980-2010: Interactions with National and Global Dynamics," TÜBITAK Project No. $108 K 511$ (2012), unpublished report. For a comparison with the Ministry of Finance, see Caner Bakır, "Maliye Bürokrasisinde Örgütsel Değişim ve Vergi Denetim Kurulu Başkanlığının Kurulması," Amme Idaresi Dergisi 45, no. 2 (2012): 81-102.

47 For a detailed discussion, see Bakır and Çoban, "Policy Analysis and Capacity in the Central Bank of Turkey." 
developing countries, including Turkey. ${ }^{48}$ These hot money inflows resulted in the appreciation of the Turkish lira, excess bank credit growth, and increased household leverage, which led to a widening current account deficit. To manage these macrofinancial risks, the Central Bank acted proactively and introduced a "new policy mix" by experimenting with an "unconventional monetary policy" in November 2010. ${ }^{49}$

The Central Bank's new policy mix involved an asymmetric interest rate corridor and a reserve option mechanism. The former aimed to establish a flexible monetary policy to encourage or deter hot money flows without changing the policy rate, while the latter directed banks to accumulate foreign reserves at the Central Bank by depositing foreign currency and/or gold in lieu of Turkish lira reserve requirements. ${ }^{50}$ The aim was to sterilize capital inflows and stabilize the foreign exchange rate in times of surge or decline in capital inflows. ${ }^{51}$

While these two policy instruments demonstrate the proactive stance taken by the Central Bank against the adverse effects of capital inflows, it soon became clear that the new policy mix was not effective in containing bank credit growth, and so it had to be complemented by macroprudential policy measures such as risk weights, provisioning, and maturity restrictions targeting the rapid growth of consumer loans and increased household leverage. ${ }^{52}$ In this respect, the Central Bank played a principal role in the establishment of the FIK in June 2011, which resulted in macroprudential tightening by the BDDK in order to contain the macrofinancial risks. ${ }^{53}$

Recent research has identified six key analytical and operational sources of the policy capacity of the Central Bank during this period: (1) the ready availability of quality data; (2) human capital with high technical knowledge and expertise in evidence-based policy analysis and advice; (3) recruitment and career development practices enhancing policy analysis; (4) horizontal organizational arrangements facilitating more interdepartmental interaction, communication, and collaboration; (5) an organizational culture based on open discussions and risk-taking, thereby promoting policy innovation; and

48 IMF, "Recent Experiences in Managing Capital Flows."

49 Kara, "Turkey's Experience with Macroprudential Policy."

50 Alper et al., "Alternative Tools to Manage Capital Flow Volatility."

51 Türkiye Cumhuriyeti Merkez Bankası (TCMB), Financial Stability Report (Ankara: Central Bank of the Republic of Turkey, December 2010), 37; Hakan Kara and Çağrı Sarıkaya, "Türkiye'de Konjonktürel Etkilerden Arındırımış Cari Işlemler Dengesi," Working Paper no. 13/40 (Ankara: Central Bank of the Republic of Turkey, November 2013), 18.

52 Kara, "Monetary Policy in Turkey after the Global Crisis," 5; see also Gürkaynak et al., "Monetary Policy in Turkey after Central Bank Independence"; Hakan Kara, "A Brief Assessment of Turkey's Macroprudential Policy Approach: 2011-2015," Central Bank Review 16, no. 3 (2016): 85-92.

53 Bakır and Çoban, "Policy Analysis and Capacity in the Central Bank of Turkey"; Kara, "A Brief Assessment"; Yağcı, "Institutional Entrepreneurship and Organisational Learning." 
(6) the policy learning and transfer capabilities arising from interactions with the transnational epistemic community of central bankers. ${ }^{54}$ In addition to these resources and capabilities, the Central Bank also had the political capacity to generate the much-needed political support that would help to translate its policy preferences into government policies. Indeed, the "political support given to the Central Bank's policy design and implementation is the most critical type of [organizational policy] capacity" allowing it to address the macrofinancial risks. ${ }^{55}$

Given all this, the overriding question is as follows: how does the organizational capacity of the Central Bank affect monetary and macroprudential policy design and implementation, with special reference to the containment of macrofinancial risks through the new monetary policy mix and macroprudential regulation?

Our interviews revealed that the design and implementation of the new policy mix and the introduction of macroprudential measures following the establishment of the FIK were informed by these various forms of policy capacity. In regard to the principal sources of analytical, operational, and political capacity at the Central Bank, all of the senior interviewees at the Central Bank noted that the governor of the Central Bank at the time, Erdem Başçı, was the principal agent. Baş̧̧ took a leadership role in the introduction of the asymmetric interest rate corridor and the establishment of the FIK, whilst also empowering and encouraging other senior central bankers to engage in the reserve option mechanism. In the words of a former deputy governor of the Central Bank: "Erdem [Başçı] can quickly translate an idea into a policy [...] Deputy governors are also important, but it is the governor who is a leader. He was very active, with high potential and strong credentials. Thus his mindset translates an abstract idea into a policy." ${ }^{16}$

Baş̧̧ was an economist at a research university before being appointed to the Central Bank. When the Justice and Development Party (Adalet ve Kalkınma Partisi, AKP) came to power in November 2002, Baş̧̧ initially served as an advisor to Minister of Economy and Deputy Prime Minister Ali Babacan, after which he served as a deputy governor of the Central Bank for eight years before being appointed as governor, a capacity in which he served between April 2011 and April 2016. As this career path indicates, Başçı had multiple professional identities as a respected academic, policy advisor, and decision maker in his role at the Central Bank, and this enabled him to operate at the intersection of policy design and implementation. For

54 Bakır and Çoban, "Policy Analysis and Capacity in the Central Bank of Turkey," 228.

55 Ibid.

56 Interview, CB3, İstanbul, February 22, 2019. 
example, he championed using an asymmetrical corridor as a policy instrument for a new objective: capital flow management. As noted by a senior central banker:

It was the governor who was most influential in the adoption of the policy [i.e., the asymmetric interest rate corridor]. I also believed that we needed to implement something new [...] The Turkish lira was overvalued and capital inflows were fast. When these issues [large capital inflows and their associated risks] came to our agenda, there was a need for a new [policy] tool. ${ }^{57}$

In the words of the governor himself, "During the Euro zone crisis we seriously [took] this [tool] into account. A very wide and asymmetric interest rate corridor served its function [...] when we tightened liquidity policy. In a short period of time we achieved the desired objective. ${ }^{58}$

It is widely recognized that "[i]n the new policy design orientation understanding the origins and implications of the ideas held by decision-makers and advisors is a major subject of analysis." ${ }^{59}$ Yet there is no simple answer to the question posed above, as it is difficult to track the origins of policy ideas due to the "infinite regress" problem. ${ }^{60}$ Nevertheless, an asymmetrical corridor as a new liquidity management tool in central banking clearly represents an elaboration of an idea put forward by Charles Goodhart, a former member of the Bank of England's Monetary Policy Committee and a professor at the London School of Economics. In a November 2009 speech entitled "Liquidity Management" and presented at the Jackson Hole Economic Policy Symposium organized by the Federal Reserve Bank of Kansas, ${ }^{61}$ Goodhart became the first academic to advocate an asymmetrical corridor as a policy tool for central banks to manage liquidity. ${ }^{62}$

57 Interview, CB4, Ankara, January 6, 2013.

58 Interview, CB1, Ankara, December 7, 2013.

59 Michael Howlett, "From the 'Old' to the 'New' Policy Design: Design Thinking beyond Markets and Collaborative Governance," Policy Sciences 47, no. 3 (2014), 196; see also Mark Considine, "Thinking Outside the Box? Applying Design Theory to Public Policy," Politics \& Policy 40, no. 4 (2012): 704-724.

60 Andrew Bennett, "Process Tracing and Causal Inference," in Rethinking Social Inquiry: Diverse Tools, Shared Standards, ed. Henry E. Brady and David Collier (Plymouth: Rowman \& Littlefield Publisher, Inc., 2004), 209.

61 Charles Goodhart, "Liquidity Management," Proceedings - Economic Policy Symposium - Jackson Hole (Kansas City, MO: Federal Reserve Bank of Kansas City, 2009): 157-168, =https://www.kansascityfed. org/ /media/files/publicat/sympos/2009/papers/goodhart091109.pdf?la=en.

62 Goodhart's abstract policy idea, which was proposed for developed country central banks for liquidity management in the post-GFC period, was translated into a policy instrument for capital flow management by the Central Bank. Specifically, Goodhart's idea to use the upper and lower limits of the corridor in a way that was more dynamic than constant, more asymmetric than symmetric, and more innovative than traditional influenced the monetary policy design and implementation targeting capital flows at the Central Bank. 
Baş̧ noted that Goodhart's policy idea informed his own design thinking and legitimized the Central Bank's implementation of an asymmetric interest rate corridor:

There was a talk by Professor Charles Goodhart in Jackson Hole [ . . . ] where he notes that the asymmetrical interest rate corridor is a highly useful policy tool, but it has been neglected and not used by the central banks [...] Although I did not attend the [symposium] I did read the article. We also referred to [Goodhart's] article when we described our policy implementation in [national and international] meetings. ${ }^{63}$

Besides the governor, deputy governors serving as members of the Monetary Policy Committee (Para Politikası Kurulu) are also recognized as key individual actors in forming the backbone of the Central Bank's analytical and operational policy capacity. These individuals were referred to by our interviewees as "innovative," "open to new ideas and dialogue," "like-minded," and "competent." One such individual noted as follows:

Our advantage [in the policy design and implementation] was that there was a group of managers from academia. They like to think outside the box. Thus, there was not much bureaucratic inertia. [In regard to calibrating the monetary policy mix] we did some brainstorming $[\ldots]$ we discussed what would work and not work [...] We had the presence of well-rounded academics who could make quick decisions, think outside the box, [and] implement [...] They did not hesitate to consider new policy ideas. Academics are like that. They are interested in fresh ideas and approaches on [capital flow management]. They look [at policy issues] from a different angle. ${ }^{64}$

In this respect, these individuals constituted a "dream team" closely cooperating and collaborating with each other in monetary policy design and implementation. These senior officers of the Central Bank perform the role of both policy analysts and decision makers. All the senior central bankers we interviewed referred to the significance of having academics with training in economics at the top of the bank's decision-making hierarchy:

We follow developments in the world closely [...] When one of us sees or identifies something, we can communicate that with one another in five to ten sentences during a five-minute face-to-face talk. Such an understanding of each other is of the utmost importance [in initiating discussions on new ideas and policies]. In its absence you get nowhere [...] We speak the same

63 Interview, CB1, Ankara, December 7, 2013.

64 Interview, CB4, Ankara, January 25, 2019, and December 6, 2013. 
language. More significantly, the governor internalizes new policy ideas [such as the reserve option mechanism] and supports them immediately. This is not an easy thing in central banking when you introduce a new policy. ${ }^{65}$

In addition to their academic background, the senior decision makers were also socialized so as to share common programmatic policy ideas through attendance at various international meetings, which complemented their agentive role in policy design and implementation at the Central Bank. In the words of one deputy governor, "the policy formulation is done by the top management because they attend the major meetings at the BIS (Bank for International Settlements), the Financial Stability Board, the G20, and the IMF, where they understand markets [and] get feedback." ${ }^{\prime 6}$

The interviewees also highlighted the relationship between these individual agency-level complementarities among senior central bankers on the one hand and, on the other, the organizational culture at the Central Bank, which informed its analytical policy capacity: "The staff know their job well. They do not have feelings of inferiority. They are open to dialogue and new ideas. They can be convinced. They do not drag their feet when you need interdepartmental cooperation [...] You cannot impose things from the top down." ${ }^{67}$ On the same note, another interviewee said:

Bureaucrats, at the end of the day, consider their superiors' response to new ideas. I mean, "Will he understand me?" And, "If I bring a new idea to his attention would he be interested in it or not? Or would he [just] say, "Why are you meddling in my affairs'?" These are very important. That's why top management is of the utmost importance. It is about their openness to subordinates [in policy design and implementation]. ${ }^{68}$

These horizontal organizational and institutional arrangements facilitate more interdepartmental interaction, interpersonal trust, communication, and collaboration, which in turn strengthens staff morale and interpersonal relations: "A new university graduate, an assistant economist, can make a presentation to the Monetary Policy Committee with confidence and without a fear of expressing his ideas." ${ }^{\circ 9}$

In regard to the implementation of new policy ideas, the Central Bank's communication strategy is recognized as an important part of its operational capacity. This is because it increases the legitimacy and predictability of the

65 Interview, CB3, Istanbul, February 22, 2019.

66 Interview, CB2, İstanbul, February 22, 2019.

67 Interview, CB3, İstanbul, February 22, 2019.

68 Interview, CB2, İstanbul, February 22, 2019.

69 Interview, CB2, İstanbul, February 22, 2019. 
Central Bank's actions, as well as the effective management of its policy instruments in managing capital flows. In the words of one deputy governor:

After developing a new policy, you need to communicate it. You need to share your ideas with stakeholders who might be citizens, politicians, bankers $[\ldots]$ and convince them. Thus, their expectations will change [...] I remember the "new policy mix" era. Those who were critical [of the policy] at the outset were convinced over time through the communication [that facilitated its effective implementation.$^{70}$

In addition to the top managers actively involved in ideational entrepreneurship and policy implementation at the Central Bank, their subordinates in the Research and Monetary Policy Department and the Banking and Financial Institutions Department were also integral to the policy design process in "explor[ing] the details" of new policy ideas and instruments. ${ }^{71}$ As one senior central banker notes:

When I was heading the Research and Monetary Policy Department, our role was to put policy ideas and actions into coherent and consistent theoretical context. This is because we need to communicate what we do. For example, we formed the Financial Stability Analysis group [within the FIK]. We had meetings two to three times a week. We examined relevant policies that might inform our policies in historical perspective. We discuss how we can do it differently [...] The participants of this group included the deputy governor, as well as managers, economists, and specialists from the Research and Monetary Policy Department and the Banking and Financial Institutions Department. Each week one of them volunteered to make a presentation on a specific topic. We were reading and discussing several relevant articles or research findings. In doing so, we were able to form the [cognitive] background of our policies. [Policy design] is triggered by the senior staff, but in these [ad hoc interdepartmental groups] we put flesh on the bones of policy ideas. It is about thinking how to strengthen policy ideas and improve their instruments. This is how upperand lower-level administration interact [in policy design and implementation]. ${ }^{72}$

The Central Bank wanted the implementation of macroprudential measures by the BDDK to complement its new policy mix in its effort to contain macrofinancial risks. The main reason behind the initial establishment of the FİK was, in the words of one deputy governor, to "support the Central Bank's financial stability measures [i.e., the new policy mix] with the BDDK's

70 Interview, CB2, İstanbul, September 17, 2016.

71 Interview, CB3, Istanbul, February 22, 2019.

72 Interview, CB4, Ankara, January 25, 2019. 
macroprudential regulatory policy." ${ }^{73}$ In a similar vein, the deputy chairman of the BDDK mentioned that, "since the capital inflows were not [influenced as expected] by the Central Bank, the Central Bank requested the BDDK to implement regulatory measures [in the FIKK meetings]."

In linking its policy preferences with the governmental agenda, the Central Bank relied on its political capacity. For example, interviewees noted that the FİK served as a formal setting for the introduction of macroprudential policy measures as a result of Başçı's entrepreneurship. In this respect, strong interpersonal ties and mutual trust between then-governor Başç and then-minister Babacan were critical. ${ }^{75}$ The strength and content of these interpersonal ties included a shared neighborhood, childhood, and schooling. ${ }^{76}$ These ties were one of the key temporal sources of the Central Bank's political capacity to link its policy preferences with the governmental agenda setting via Babacan. Indeed, most of the interviewees from the Central Bank and the BDDK noted the importance of Başç1's access to Babacan, who was a strong "supporter" of the Central Bank in politics and markets and who "sheltered" the governor from senior politicians' fierce partisan campaigns. ${ }^{77}$

These elite decision makers "shared a common worldview" on critical policy issues such as "the need to contain excess bank credit growth, which leads to financial instability," and there was "mutual trust among them [that] was critical" in the translation of the Central Bank's policy preferences into governmental policies. ${ }^{78}$ Unsurprisingly, they were on the same page in regard to the interbureaucratic design and implementation of the portfolio of the monetary policy mix and macroprudential measures. This was one of the key temporal sources of political capacity, in this instance enhancing both the Central Bank's policy capacity and state capacity. One senior central banker explained the significance of the political capacity as follows:

It is of the utmost importance that the governor and the minister be on the same page $[\ldots]$ Trust is the most significant factor in this respect. It makes a

73 Interview, CB2, İstanbul, September 17, 2016.

74 Interview, R1, Ankara, January 11, 2016.

75 Ali Babacan served as the Deputy Prime Minister for Economic and Financial Affairs between 2009 and 2015, during the 61st and 62nd governments of the Republic of Turkey; see Türkiye Büyük Millet Meclisi (TBMM), "Ali Babacan," Türkiye Büyük Millet Meclisi, ==https://www.tbmm.gov.tr/develop/ owa/milletvekillerimiz_sd.bilgi?p_donem=26\&p_sicil=6063.

76 "Babacan, 5 Yıl Bekledi Çıkrıkçılar'dan Arkadaşını Merkez'in Başına Taşıdı," Hürriyet, April 15, 2011, http://www.hurriyet.com.tr/babacan-5-yil-bekledi-cikrikcilar-dan-arkadasini-merkez-in-basina-tasidi17550789.

77 See also "Erdogan Backs off in Battle with Turkish Central Bank," Financial Times, March 12, 2015, https://www.ft.com/content/205c72f6-c89d-11e4-8617-00144feab7de; Caner Bakır, "Merkez Bankası Başkanları ve Siyasetçiler," Kurumsal Yatııımcı Dergisi (April-June 2015): 56-57.

Interview, CB4, Ankara, January 25, 2019. 
big difference for a minister if he trusts his bureaucrat. I remember [... ] I made a presentation to the minister and we were together with Erdem Başç when he was a deputy governor. Our proposals in my presentation were implemented within two to three days by the government [ ...] [As another example,] the establishment of the Financial Stability Committee was very fast. If you planned such a committee in Switzerland it would take three years. We had [the FiK] established within one month or so after thinking of it. The minister was pivotal in this outcome [...] The presence of a trusted minister was important for [top bureaucrats at the Central Bank] and for the governor, because central bankers moved forward with his support. Although the Central Bank had instrument independence, our decisions affect the economy directly. Thus there is a need for support from state managers. In the absence of this, things do not work. ${ }^{79}$

In light of this, the same interviewee noted the following:

The Central Bank's autonomy is temporal. The Central Bank has a law. However, its operationalization of what has been written in this law depends on your relations with politicians. It changes across time and depends on personalities. We do not have a tradition on this issue in this country. It is so new. The Central Bank's law [strengthening its legal independence from politicians] dates back to 2001. Some other central banks have 200 years of experience. We do learn these things over time by making mistakes, hitting the wall, and paying the price. ${ }^{80}$

Finally, it should be noted that the Central Bank's organizational policy capacity was not the only factor contributing to the new policy ideas and their instruments. This was of course a necessary condition, but it alone was not sufficient to design and implement, for example, the new policy mix. The existence of structural, institutional, and agency-level complementarities reinforce effective policy design and implementation, which generates desired policy outcomes. ${ }^{81}$ One senior central banker made this point nicely:

It is a necessary condition. Because there are three pillars of [policy design and implementation] at the Central Bank. First, the trust of the politician of the Central Bank. Second, the Central Bank's policy design and implementation capacity. Third, conducive global conjecture that reinforces the Central Bank's actions. I say if any one of these is missing, it won't work. ${ }^{82}$

79 Interview, CB4, Ankara, January 25, 2019; emphasis ours.

80 Ibid.

81 For a detailed discussion of the effect of complementarities arising from interactions among structures, institutions, and agents, see Bakır, Bank Behaviour and Resilience.

82 Interview, CB4, Ankara, January 25, 2019. 
Regarding the conducive global conjecture, the GFC as a structural context led to a shift in programmatic policy ideas, from microprudential regulation to macroprudential regulation. In addition to the Central Bank's capacity at the organizational level and the political support that it received, this ideational shift also created institutional complementarity that reinforced the Central Bank's experimentation with the new policy mix and its call for the establishment of the FIK. As a new consensus of the transnational epistemic community in finance, "the idea of macroprudential regulation (MPR) moved to the centre of the policy agenda and became the principal interpretative frame for financial technocrats and regulators seeking to navigate the [GFC] and respond to it, not only in terms of diagnosing and understanding it, but also in advancing institutional blueprints for regulatory reform." 83 As one interviewee stated:

It is difficult to implement something new. Your global stakeholders [e.g., the international financial community, the BIS, and the IMF] do not let you do it since it runs [against] widely accepted conventional wisdom among central bankers. There are commonly accepted central banking principles. You cannot deviate from them easily. However, the GFC challenged some of these principles. This created a space for us to try new ideas and instruments. ${ }^{84}$

\section{Concluding remarks}

This article has examined Turkey's proactive stance against the surge in capital inflows in the post-GFC period to contain macrofinancial risks, with special reference to the Central Bank's organizational policy capacity. We have argued that the design and implementation of proactive policy measures are more likely to complement state capacity when the principal bureaucratic actors have a strong organizational policy capacity. Specifically, this article has shown that strong state capacity in maintaining financial stability in a proactive monetary and macroprudential policy design and implementation is most likely when the principal bureaucratic actors have strong analytical, operational, and political capacities. Despite this, when the Turkish lira plummeted to record lows against major currencies in August 2018, it became clear that, while

83 Andrew Baker, "The New Political Economy of the Macroprudential Ideational Shift," New Political Economy 18, no. 1 (2013), 113; emphasis ours; see also Lucia Quaglia, "Financial Regulation and Supervision in the European Union after the Crisis," Journal of Economic Policy Reform 16, no. 1 (2013): 17-30.

84 Interview, CB4, Ankara, January 25, 2019. 
strong organizational policy capacity is certainly one of the necessary conditions in maintaining macrofinancial stability, it is not sufficient on its own. As Kara rightly notes, "it is also important to note that macroprudential policies cannot be a substitute for sound structural reforms. In many cases, macroprudential policies can rather be regarded as second-best solutions that save time until deeper structural adjustments [e.g., macroeconomic reforms] take place." 85

In a world of complex monetary policymaking, central banks around the world need to have high analytical and operational capacities, which are internal sources of policy capacity. Yet they also need to have the political capacity to be able to translate their policy preferences to the governmental agenda. This article emphasizes how the much-neglected political support given to the Central Bank's policy design and implementation is the most critical type of capacity. This is an external source of policy capacity.

This finding offers valuable insight into the central bank independence literature, which has overemphasized central banks' independence from politicians. This dominant paradigm in central banking ignores the fact that central bankers need the support of politicians if they wish to translate their policy preferences into actual government action. Furthermore, it must be noted that politicians are not homogenous entities sharing the same beliefs or policy prescriptions. For example, some politicians tend to intervene in monetary policy, whilst others share central bankers' worldviews and advance their preferences in the bureaucratic and political arenas. In doing so, they strengthen state capacity by steering policy formulation and implementation.

Policy actions are contingent upon both temporal and non-temporal contexts. ${ }^{86}$ The caveat in our analysis is that the overall capacity of the Turkish state, and that of the Central Bank in particular, is contextually contingent. Thus, the state capacity and the organizational capacity are volatile. This has become more visible with the seismic political regime change taking place at the structural level in Turkey. Unsurprisingly, the Central Bank's policy capacity has been eroding in the years following its introduction of the "new policy mix." While organizational policy capacity enables evidencebased policymaking and policy experimentation that contribute to a lower inflation rate, output, and financial stability, ${ }^{87}$ the Central Bank's autonomy

85 Kara, "Turkey's Experience with Macroprudential Policy," 137.

86 Caner Bakır and Darryl S.L. Jarvis, "Contextualizing the Context in Policy Entrepreneurship and Institutional Change," Policy and Society 36, no. 4 (2017): 465-478.

87 Alberto Alesina and Lawrence H. Summers, "Central Bank Independence and Macroeconomic Performance: Some Comparative Evidence," Journal of Money, Credit and Banking 25, no. 2 (1993): 151-162; Jeroen Klomp and Jakob de Haan, "Inflation and Central Bank Independence: A Meta-regression Analysis," Journal of Economic Surveys 24, no. 4 (2010): 593-621; Roman Horváth and Dan Vaško, "Central Bank Transparency and Financial Stability," Journal of Financial Stability 
has not been internalized by the government. This is clearly evidenced by senior politicians' recent fierce partisan campaigns for lower interest rates and their efforts to blame the Central Bank's interest rate policy for causing inflation, lower economic growth, and investment rates. ${ }^{88}$ Following the departure of Baş̧ in April 2016, the analytical, operational, and political sources of organizational policy capacity were dismantled. Political intervention became most visible with the government's dismissal of Başç's successor as the governor of the Central Bank, Murat Çetinkaya, following a presidential decree on July 6 , 2019 - nearly one year before the official end of his term in $2020{ }^{89}$ Thus, the organizational policy capacity of a central bank is by no means isolated from its formal or informal independence from populist politicians.

We have found that the Central Bank's policy autonomy is temporal: it depends on interpersonal relations between senior central bankers and politicians, as well as on whether they have mutual trust and a shared understanding of policy challenges and their solutions. Specifically, it was significant that the governor of the Central Bank and the Minister of the Treasury shared the view that the macrofinancial policies had to slow down excessive bank credit growth. This finding offers insight into the existing research on the rise and decline of bureaucratic autonomy in Turkey. Our research confirms the view that Turkey has recently opted "for de-delegation, centralization of decision making, increasing political control over economic governance, and a retreat from the norms of good governance via independent agencies." 90 In this context, however, it is also noted that the "independence of the Central Bank is preserved" because "the risk in endangering independence would be substantial, not only because of probable repercussion[s] in other sectors, but also the importance of signaling investors, rating agencies, and the like" or "the links between central bank independence and capital inflows as well as IMF loans." ${ }^{11}$ In contrast, we have shown that the temporality of the

22 (2016): 45-66; Christopher Crowe, Ellen Christopher W. Crowe, and Ellen E. Meade, "Central Bank Independence and Transparency: Evolution and Effectiveness," European Journal of Political Economy 24, no. 4 (2008): 763-777.

88 See "Erdogan Backs off in Battle with Turkish Central Bank," Financial Times, March 12, 2015; Bakır, "Merkez Bankası Başkanları ve Siyasetçiler."

89 Cağan Koç and Onur Ant, "Erdogan Ousts Central Bank Chief Who Drew Ire For Holding Rates," Bloomberg July 6, 2019, https://www.bloomberg.com/news/articles/2019-07-06/erdogan-removescetinkaya-names-deputy-as-central-bank-governor.

90 Isik Ozel, "The Politics of De-delegation: Regulatory (In)dependence in Turkey," Regulation \& Governance 6, no. 1 (2012), 119. See also Tamer Çetin et al., "Independence and Accountability of Independent Regulatory Agencies: The Case of Turkey," European Journal of Law and Economics 41, no. 3 (2016): 601-620. For a similar view in the context of central banking, see Caner Bakır, "Policy Entrepreneurship and Institutional Change: Multi-level Governance of Central Banking Reform," Governance: An International Journal of Policy, Administration and Institutions 22, no. 4 (2009): 571-598.

91 Isik Ozel, "The Politics of De-delegation," 126. 
Central Bank's independence and autonomy are informed by the interpersonal relations between senior central bankers and politicians. In the absence of trust and a shared understanding of policy issues, monetary policy formulation and implementation become increasingly subject to partisan challenges, which in Turkey have been more severe than those of the pre-2001 period..$^{92}$ More political intervention certainly undermines the Central Bank's confidence, commitment, and interest in providing innovative policy advice and implementation. Moreover, politicians are increasingly intervening in senior appointments, staff recruitment, career development, and promotion, which have all become more influenced by political criteria. This adversely affects the bank's ability to attract and retain analysts with the requisite skills, knowledge, and expertise, and it also has a negative effect on staff morale and interpersonal relations. These accelerating challenges will erode not only the policy capacity of the Central Bank, but also that of the Turkish state in the financial services industry. Given the current partisan interventions into various policy sectors, one should not be surprised if one observes policy design and implementation failures, poor policy outcomes, and increased socioeconomic costs in Turkey in future.

It is essential to note, though, that the politicization of central banking is not confined to the Turkish context, as it has gained pace around the world in the post-GFC period. There are several factors, which also apply to the Turkish context, driving this trend. For example, macroprudential policy can cause conflict between politicians and the central banks because measures imposed to cool down a booming economy might not be politically desirable. ${ }^{93}$ The major central banks, for example, have shied away from using countercyclical macroprudential measures due to the politicization of central banking, among other factors, such as a lack of adequate data and analysis. ${ }^{94}$ Finally, the distributional aspects of monetary policy and macroprudential policy pave the way for the politicization of central banking, as the rise of populism forces politicians to intervene in the conduct of monetary policy and macroprudential policy in order to meet societal demands. ${ }^{95}$ Considering the politicization of central banking under these circumstances, we may expect more government intervention into central banking around the world.

92 See Bakır, Merkezdeki Banka ve Uluslararası Bir Karşılaştırma.

93 Andrew Baker, "The Political Economy and Paradoxes of Macroprudential Regulation," SPERI Paper no. 40 (Sheffield: Sheffield Political Economy Research Institute, March 2017), 11. It should be noted that Babacan and Başcl, both of whom agreed on limiting bank credit growth and jointly took policy measures, represented a novel exception to this tendency.

94 Matthias Thiemann, "Is Resilience Enough? The Macro-Prudential Reform Agenda and the Lacking Smoothing of Cycle," Public Administration 97, no. 3 (2019): 561-575.

95 Charles Goodhart and Rosa Lastra, "Populism and Central Bank Independence," Open Economies Review 29, no. 1 (2018): 49-68. 


\section{References}

Akcelik, Yasin, Ahmet Faruk Aysan, and Arif Oduncu. "Central Banking in Making during the Post-crisis World and the Policy-Mix of the Central Bank of the Republic of Turkey." Journal of Central Banking Theory and Practice 2, no. 2 (2013): 5-18.

Akyüz, Yilmaz and Korkut Boratav. "The Making of the Turkish Financial Crisis." World Development 31, no. 9 (2003): 1549-1566.

Alesina, Alberto and Lawrence H. Summers. "Central Bank Independence and Macroeconomic Performance: Some Comparative Evidence." Journal of Money, Credit and Banking 25, no. 2 (1993): 151-162.

Alper, Koray, Hakan Kara, and Mehmet Yörükoğlu. "Alternative Tools to Manage Capital Flow Volatility." BIS Papers 73 (2013): 335-352.

Aysan, Ahmet Faruk, Salih Fendoğlu, and Mustafa Kilinc. "Macroprudential Policies as Buffer against Volatile Cross-border Capital Flows." The Singapore Economic Review 60, no. 1 (2015): 1-6.

Baker, Andrew. "New Political Economy of the Macroprudential Ideational Shift." New Political Economy 18, no. 1 (2013): 112-139.

- The Political Economy and Paradoxes of Macroprudential Regulation." SPERI Paper no. 40. Sheffield: Sheffield Political Economy Research Institute, 2017.

Bakir, Caner. "Governance by Supranational Interdependence: Domestic Policy Change in the Turkish Financial Services Industry." In Emerging European Financial Markets: Independence and Integration Post-Enlargement. Edited by Jonathan Batten and Colm Kearney. London: Elsevier, 2006. 179-211.

—_. Türkiye Cumhuriyet Merkez Bankası'nın 1930-2001 Arasında Siyasal ve Ekonomik Bağımsızlığı: Siyasal-Ekonomik Etkileşime İlişkin Karşılaştırmalı Bir Çözümleme." METU Studies in Development 33, no. 1 (2006): 1-31.

—. Merkezdeki Banka ve Uluslararası Bir Karşılaştırma. İstanbul: Bilgi University Press, 2007.

_. "The Governance of Financial Regulatory Reform: The Australian Experience." Public Administration 87, no. 4 (2009): 910-922.

—. "Policy Entrepreneurship and Institutional Change: Multi-level Governance of Central Banking Reform." Governance: An International Journal of Policy, Administration and Institutions 22, no. 4 (2009): 571-598.

—. "Maliye Bürokrasisinde Örgütsel Değişim ve Vergi Denetim Kurulu Başkanlığının Kurulması." Amme Idaresi Dergisi 45, no. 2 (2012): 81-102.

- Bank Behavior and Resilience: The Effects of Structures, Institutions and Agents. Basingstoke: Palgrave Macmillan, 2013.

—. "Bargaining with Multinationals: Why State Capacity Matters." New Political Economy 20, no. 1 (2015): 63-84.

. "Merkez Bankası Başkanları ve Siyasetçiler." Kurumsal Yatirimci Dergisi (April-June, 2015): 56-57.

. "How Can Interactions among Interdependent Structures, Institutions, and Agents Inform Financial Stability? What We Have Still to Learn from Global Financial Crisis." Policy Sciences 50, no. 2 (2017): 217-239.

- "Actions, Contexts, Mechanisms and Outcomes in Macroprudential Policy Design and Implementation." Public Policy and Administration (2019). doi: 10.1177/0952076719827057.

Bakir, Caner and Ziya Öniş. "The Regulatory State and Turkish Banking Reforms in the Age of postWashington Consensus." Development and Change 41, no. 1 (2010): 77-106.

Bakir, Caner and Darryl S. L. Jarvis, "Contextualising the Context in Policy Entrepreneurship and Institutional Change." Policy and Society 36, no. 4 (2017): 465-478.

Bakir, Caner and J. J. Woo. "Financial Sector Reform and Policy Design in an Age of Instability." Policy and Society 35, no. 3 (2016): 193-204.

Bakir, Caner and Mehmet Kerem Coban. "Policy Analysis and Capacity in the Central Bank of Turkey." In Policy Analysis in Turkey. Edited by Caner Bakir and Güneş Ertan. Bristol: Policy Press, 2018. 215-233.

Başçı, Erdem and Hakan Kara. "Finansal Istikrar ve Para Politikası." Working Paper no. 11/08. Ankara: Central Bank of the Republic of Turkey, May 2011. 
Bennett, Andrew. "Process Tracing and Causal Inference." In Rethinking Social Inquiry: Diverse Tools, Shared Standards. Edited by Henry E. Brady and David Collier. Plymouth: Rowman \& Littlefield Publisher, Inc., 2010. 207-219.

Coban, Mehmet Kerem. "Compliance Forces, Domestic Policy Process, and International Regulatory Standards: Compliance with Basel III.” Business and Politics (2019). doi: 10.1017/bap.2019.3.

Coleman, William D. Financial Services, Globalization and Domestic Policy Change. New York: St. Martin's Press, 1996.

Considine, Mark. "Thinking Outside the Box? Applying Design Theory to Public Policy." Politics \& Policy 40, no. 4 (2012): 704-724.

Crowe, Christopher and Ellen E. Meade. "Central Bank Independence and Transparency: Evolution and Effectiveness." European Journal of Political Economy 24, no. 4 (2008): 763-777.

Çetin, Tamer, M. Zahid Sobacı, and Mehmet Nargeleçekenler. "Independence and Accountability of Independent Regulatory Agencies: The Case of Turkey." European Journal of Law and Economics 41, no. 3 (2016): 601-620.

Demiralp, Seda and Selva Demiralp. "Erosion of Central Bank Independence in Turkey." Turkish Studies 20, no. 1 (2019): 49-68.

Evans, Peter B. Embedded Autonomy: States and Industrial Transformation. Princeton, NJ: Princeton University Press, 1995.

Evans, Peter B., Dietrich Rueschemeyer, and Theda Skocpol, eds. Bringing the State Back In. Cambridge: Cambridge University Press, 1985.

Flug, Kranit. "Policy Analysis at the Bank of Israel." In Policy Analysis in Israel. Edited by Gila Menahem and Amos Zehavi. Bristol: Policy Press, 2016. 141-152.

Fukuyama, Francis. State-Building: Governance and World Order in the 21st Century. Ithaca, NY: Cornell University Press, 2003.

Garcia-Escribano, Mercedes and Fei Han. "Credit Expansion in Emerging Markets: Propeller of Growth?" IMF Working Papers no. 15/22. Washington, DC: International Monetary Fund, 2015.

Goodhart, Charles. “Liquidity Management." Proceedings - Economic Policy Symposium - Jackson Hole. Kansas City, MO: Federal Reserve Bank of Kansas City, 2009. 157-168. =https://www.kansascityfed. org/ /media/files/publicat/sympos/2009/papers/goodhart091109.pdf?la=en.

Goodhart, Charles and Rosa Lastra. "Populism and Central Bank Independence." Open Economies Review 29, no. 1 (2018): 49-68.

Gürkaynak, Refet S., Zeynep Kantur, M. Anıl Taş, and Seçil Yıldırım. "Monetary Policy in Turkey after Central Bank Independence." Iktisat, Isletme ve Finans 30, no. 356 (2015): 9-38.

Head, Brian W. "Reconsidering Evidence-based Policy: Key Issues and Challenges." Policy and Society 29, no. 2 (2010): 77-94.

Hielscher, Kai and Gunther Markwardt. "The Role of Political Institutions for the Effectiveness of Central Bank Independence." Journal of European Political Economy 28, no. 3 (2012): 286-301.

Horváth, Roman and Dan Vaško. "Central Bank Transparency and Financial Stability." Journal of Financial Stability 22 (2016): 45-66.

Howlett, Michael. "Policy Analytical Capacity and Evidence-based Policy-making: Lessons from Canada." Canadian Public Administration / Administration Publique du Canada 52, no. 2 (2009): 153-175.

. Designing Public Policies: Principles and Instruments. Abingdon: Routledge, 2011.

. "From the 'Old' to the 'New' Policy Design: Design Thinking beyond Markets and Collaborative Governance." Policy Sciences 47, no. 3 (2014): 187-207.

. "The Criteria for Effective Policy Design: Character and Context in Policy Instrument Choice." Journal of Asian Public Policy 11, no. 3 (2018): 245-266.

Howlett, Michael and M. Ramesh. "Globalization and the Choice of Governing Instruments: The Direct, Indirect, and Opportunity Effects of Internationalization." International Public Management Journal 9, no. 2 (2006): 175-194.

. "The Two Orders of Governance Failure: Design Mismatches and Policy Capacity Issues in Modern Governance." Policy and Society 33, no. 4 (2014): 317-327. 
_. "Achilles' Heels of Governance: Critical Capacity Deficits and Their Role in Governance Failures." Governance 10, no. 4 (2016): 301-313.

Huitema, Dave, Andrew Jordan, Stefania Munaretto, and Mikael Hildén. "Policy Experimentation: Core Concepts, Political Dynamics, Governance and Impacts." Policy Sciences 51, no. 2 (2018): 143-159.

International Monetary Fund (IMF). Recent Experiences in Managing Capital Flows: Cross-Cutting Themes and Possible Policy Framework. Washington, DC: International Monetary Fund, 2011. http://www.imf. org/external/np/pp/eng/2011/021411a.pdf.

_. "Monetary Policy in Turkey after the Global Crisis." Working Paper no. 12/17. Ankara: Central Bank of the Republic of Turkey, June 2012.

—_. "Turkey's Experience with Macroprudential Policy." BIS Papers 86 (2016): 123-139.

__. "A Brief Assessment of Turkey's Macroprudential Policy Approach: 2011-2015." Central Bank Review 16, no. 3 (2016): 85-92.

Kara, Hakan and Çağıı Sarıkaya. "Türkiye'de Konjonktürel Etkilerden Arındırılmış Cari Işlemler Dengesi." Working Paper no. 13/40. Ankara: Central Bank of the Republic of Turkey, November 2013.

Klomp, Jeroen and Jakob de Haan. "Inflation and Central Bank Independence: A Meta-regression Analysis." Journal of Economic Surveys 24, no. 4 (2010): 593-621.

Katzenstein, Peter J. Between Power and Plenty: Foreign Economic Politics of Advanced Industrial States. Madison, WI: University of Wisconsin Press, 1978.

Koç, Çağan and Onur Ant. "Erdogan Ousts Central Bank Chief Who Drew Ire for Holding Rates." Bloomberg (July 6, 2019). https://www.bloomberg.com/news/articles/2019-07-06/erdogan-removes-cetinkayanames-deputy-as-central-bank-governor.

Lodge, Martin and Kai Wegrich, eds. The Problem-solving Capacity of the State: Governance Challenges and Administrative Capacities. Oxford: Oxford University Press, 2014.

Mead, Lawrence M. "Only Connect: Why Government Often Ignores Research.” Policy Sciences 48, no. 2 (2015): 257-272.

Meltsner, Arnold J. "Political Feasibility and Policy Analysis." Public Administration Review 32, no. 6 (1972): 859-867.

Newman, Joshua. "Deconstructing the Debate over Evidence-based Policy." Critical Policy Studies 11, no. 2 (2017): 211-226.

Newman, Joshua, Adrian Cherney, and Brian W. Head. "Policy Capacity and Evidence-based Policy in the Public Service." Public Management Review 19, no. 2 (2017): 157-174.

Oliphant, Samuel and Michael Howlett. "Assessing Policy Analytical Capacity: Comparative Insights from a Study of the Canadian Environmental Policy Advice System." Journal of Comparative Policy Analysis: Research and Practice 12, no. 4 (2010): 439-445.

Ozel, Isik. "The Politics of De-delegation: Regulatory (In)dependence in Turkey." Regulation \& Governance 6, no. 1 (2012): 119-129.

Painter, Martin and Jon Pierre. "Unpacking Policy Capacity: Issues and Themes." In Challenges to State Policy Capacity: Global Trends and Comparative Perspectives. Edited by Martin Painter and Jon Pierre. London: Palgrave Macmillan, 2005. 1-18.

Quaglia, Lucia. "Financial Regulation and Supervision in the European Union after the Crisis." Journal of Economic Policy Reform 16, no. 1 (2013): 17-30.

Reinhart, Carmen M. and Vincent Reinhart. "Capital Flow Bonanzas: An Encompassing View of the Past and Present." NBER International Seminar on Macroeconomist 5, no. 1 (2008): 9-62.

Riddell, Norman. Policy Research Capacity in the Federal Government. Ottawa: Policy Research Initiative, 2007.

Skocpol, Theda. "Bringing the State Back In: Strategies of Analysis in Current Research." In Bringing the State Back In. Edited by Peter B. Evans, Dietrich Rueschemeyer, and Theda Skocpol. Cambridge: Cambridge University Press, 1985. 3-37.

Thiemann, Matthias. "Is Resilience Enough? The Macro-Prudential Reform Agenda and the Lacking Smoothing of Cycle," Public Administration 97, no. 3 (2019): 561-575.

Türkiye Cumhuriyeti Merkez Bankası (TCMB). Financial Stability Report. Ankara: Central Bank of the Republic of Turkey, December 2010. 
Uysal, Murat. "Financial Stability and Macroprudential Policy in Turkey.” BIS Papers 94 (2017): 349-364. Weiss, Linda. The Myth of the Powerless State: Governing the Economy in a Global Era. Ithaca, NY: Cornell University Press, 1998.

Wu, Xun, M. Ramesh, and Michael Howlett. "Policy Capacity: A Conceptual Framework for Understanding Policy Competences and Capabilities." Policy and Society 35, no. 3-4 (2015): 165-171.

Wu, Xun, Michael Howlett, and M. Ramesh. "Policy Capacity: Conceptual Framework and Essential Components." In Policy Capacity and Governance: Assessing Governmental Competences and Capabilities in Theory and Practice. Edited by Xun Wu, Michael Howlett, and M. Ramesh. Cham: Palgrave Macmillan, 2018. 1-25.

Yağcı, Mustafa. "Institutional Entrepreneurship and Organisational Learning: Financial Stability Policy Design in Turkey." Policy and Society 36, no. 4 (2017): 539-555.

Yin, Robert. K. Case Study Research: Design and Methods. Thousand Oaks, CA: Sage, 1994.

Zysman, John. Governments, Markets, and Growth: Financial Systems and the Politics of Industrial Change. Ithaca, NY: Cornell University Press, 1983. 